\title{
Chapter 12 \\ Epistemic Activism in the United States: \\ Examining Meetings Across the Silos of Civil Society
}

\author{
Jen Sandler
}

\section{The Challenge of Conceptualizing Civil Society's Radical Multiplicity}

Researchers of civil society face an ontological problem, well described in the ambiguous introductions to almost all of their major journals and canonical texts: What exactly is civil society? What boundaries on the field of civic action ought to be delineated so that some modes of organization can be analyzed as distinctly civic phenomena?

Howell and Pearce (2001) in "Civil Society and Development" offer a compelling distinction between two "genealogies" of civil society. In order to account for the ethical and epistemological ambiguity of concepts of civic action in the development world, Howell and Pearce argue that one must distinguish between a "mainstream genealogy" and an "alternative genealogy." The mainstream genealogy is the hegemonic intellectual history of a sphere of civic activity that is separate from the state and the market, in which citizen participation is the driving force. A healthy civil society is said to be functional for democracy, according to the mainstream genealogy, and the question becomes how civil society can be made to thrive, provide the grist for democratic life, and balance out the ethical indifference of the market.

But what of social protest against dominant political and economic structures? What of civic critique with which one attempts not to complement but to reveal and shape the landscape of power in a particular context? The civil society that operates from this mode of critique, Howell and Pearce offer, has a different genealogy. Those adopting this alternative genealogy seek a critical counter-hegemony, in Gramscian terms. It is an epistemic apparatus for making sense of an ever-expanding

\footnotetext{
J. Sandler $(\bowtie)$

Department of Anthropology, University of Massachusetts Amherst, Amherst, MA, USA

e-mail: jsandler@anthro.umass.edu
} 
range of collective projects, not simply a vantage point for engaging the center from the margins in perpetuity. The dreams of many scholar-actors working within this genealogy today are of variations on an anti-unified field that morphs perpetually on an ever-shifting bedrock of radical multiplicity (e.g., de la Cadena \& Blaser, 2018; Escobar, 2020; de Sousa Santos, 2018; Visvanathan, 2006).

In this paper, I lay out and demonstrate the utility of a radically pluralist "bigtent" approach to the study of civil society. Such a project will require appropriating the critical epistemic lens Howell and Pearce have suggested with their alternative genealogy, and which scholars of other fields have elaborated in the intervening decades, to engage with equanimity the entire field of civic action. Once researchers have broadened the field conceptually, the methodological intervention I suggest is to focus on relational and epistemic practices that center around meetings to illuminate diverse civil society projects in a new way.

\section{Bringing Civil Society into Epistemic and Relational Focus}

My interest in the "big tent" of civic action stems from my lived experience across a broad landscape of overlapping civil society projects that permeates the United States, in each major metropolitan area and at state and federal levels as well. I see a wide swath of this landscape in my various roles as researcher, engaged teacher, and civic actor. My work takes me into the worlds of applied social scientists, grassroots organizations, social movements, civic engagement projects, national and transnational networks, community care/healing groups, economic cooperatives, traditional labor unions, new labor projects, interfaith base-organizing groups, and policy advocacy organizations. The groups I work with are distinct in ideology, political stance, social identities, structural positionality, organizational structure, resources, and vision.

Most of the robust civic action I find interesting and important appears as highly fragmented and often obscure to the majority of the educated public. The illegibility of the field of civic action as a whole is largely due to the tendency of both mainstream corporate-run media and critical/leftist media to center a narrow range of questions about civic life, which are almost exclusively focus on ideologies and interests. These questions include: What do people believe? What do they want? What determines whether they get what they want? Such essentialist, positivist, and ideological questions are distinctly unhelpful for broad inquiry into the richness of civic life and are particularly unhelpful when considering diverse local contexts. Researchers must find ways to cut the field differently, to think across realms of action. The reasons for doing so are as much empirical as theoretical.

The current field of civil society is not a single field of inquiry or practice, but many. Civic action is organized, both conceptually and administratively, in silos along several lines: type of organization (social movement, foundation, non-profit); topical focus of organization (public health, housing, food, violence, education); politics (radical, reformist, technical/managerial, neoliberal, reactionary, etc.); and 
scale (local, statewide, national, transnational/international). That these silos organize how researchers engage with and conceptualize civic action is a problem for several reasons. First, actors — both human and non-human — easily move across all of the currently constituted practice fields, institutional silos, and even political ideologies. Social movement leaders become nongovernmental executives and then policy advocates or even policy makers. Analytically and ideologically distinct projects are interwoven through people's relationships. Within disciplinary silos, the situation even more absurd. Life is lived - and civic action is constituted - in the complex interplay of experiences of health, education, poverty, immigration, and so forth, and analytical or disciplinary convenience is no justification for ignoring people's lived experiences. Long critiqued, the boundaries of civic silos are not only simplistic; they are epistemically dishonest, obscuring the ways that people engage and become with and through intermingled projects, and vice versa.

Upending the silos brings up all sorts of new challenges. Researchers need methodologies with which to interrogate diverse civic projects in an honest way. Without specific ethnographic methods for engaging the field, one cannot see, for example, how development processes are met, in real time and in diverse places, through conferences to legal proceedings, local governance processes and NGO boardrooms, encounters around kitchen tables and in the streets, as part of the same broad civic dialogue about food, or state violence, or climate crisis. Researchers need methods to see, not simply theorize, "multiplicity" in civil society. Once one does away with the conceptual apparatus of silos and honestly faces the field of civil society in its multiplicity, questions of ideology recede and epistemic concerns about sense-making come to the fore.

An integrated approach to civic projects requires different questions. Returning to Howell and Pearce, those developing questions from the mainstream genealogy of civil society hold that civil society's main role is to balance competing interests, agendas, and beliefs. My questions, coming out of almost twenty years of engagement with different sorts of civic projects, are primarily epistemic and hail from the alternative genealogy: How do people come together to push upon the major structures of society - state structures, capital structures - to reframe how human thriving is understood? How do groups of people teach power to see and understand their grievances and designs the way they understand them? How do people make structures conform to their visions, or contest their legitimacy and posit alternatives? How does alternative world-making engage with particular existing worlds?

I find that efforts to shift the states', institutions', and various publics' knowledge practices (Casas-Cortés, Osterweil, \& Powell, 2008; Osterweil, 2013)—which I think of as both ways of making truth(s)/knowledge and making it matter-lie at the core of many of today's most interesting civil society projects. I call such efforts "epistemic activism." 


\section{From Participation to Epistemics}

In an important way, this approach stems from the limitations of the frame and critique of "participation" in scholarship of civil society and development. For the past 80 years, since the initiation of the global power system delineated following the Second World War, one of the primary tasks of civil society advocates has been to show the virtues of independent citizen participation for democracy. This project was reconfigured with the breakdown of the USSR and the rise of neoliberal global development plans, and notwithstanding debates about its relevance, it continues to animate funders and international bodies. During and following the decolonization period of the mid-20th century, scholars began to call attention to the epistemic violence of the colonial project of citizenship that underlies traditional notions of civil society (Fanon, 1963; Spivak, 2003). Finally, from the 1970s through the "participatory turn," one of the key projects of critical scholars in both the Global South and North has been to object to the failure of the development industry to produce real or meaningful participation-based projects (e.g., Cooke \& Kothari, 2001).

Civil society researchers have recently been fixated with the participatory turn that has unfolded since the early 1990s. The participatory turn comprises the fact that global governance, the development industry, and many large private foundations have taken up participation as a primary objective, mandate, and/or metric (see, e.g., the special issue edited by Bherer, Dufour, \& Montambeault, 2016). Many critical scholars have engaged in nuanced assessment of the participatory turn, revealing how it serves to shape civic life in such a way that citizens are often used to accomplish essentially Western global economic and political agendas, and also revealing its promise and potential (Williams, 2004). How do we depart from civic participation as a frame for civil society?

The conductors of the major civic action projects of our time are not focused on participation per se, but on advancing other values and ways of thinking: particular philanthropic orientations, "evidence-based" policy advocacy, education and health frameworks, and many of the ecological movements, spiritual movements, and radical social movements. Such diverse re-framing projects would appear obviously analytically incommensurable, and I argue that this is due to their conductors' distinct relationships to civil society's core participation concern. They stand in a different relationship to participation, to be sure: structuring it, demanding it, embodying it, eschewing it, strategizing to get it, innovating it, advocating for it. But they also do other things; they are not just detailing various modes of participation; they are advocating for ways of knowing rather than ways of participating or doing. How can we hone the conceptual and analytical resources to see such projects in a more helpful way than the participatory frame allows?

In this paper, I delineate a particular slice of the landscape of social change work in the United States cut along the epistemic dimension. Such projects are interventions into how power constructs the relationship between knowledge and the public good. I think about such efforts as organized "epistemic activist" projects and use this concept as a way of viewing the field of civil society from a different angle. 
Civil society around the globe involves a great deal of epistemic activism. It is well understood that the legacy of the post-structuralist, post-colonial, postmodernist movements is not a strong political framework or program, for that failed under the weight of myriad critiques (of irresponsible moral relativism, insufficient materialism, insufficient capacity to engage with rights-based demands, among others). But there is a strong legacy that pervades based on a stubbornly useful descriptive set of insights-Foucault's core insights: that power is inextricable from particular knowledge regimes, that governance entails at its center a relationship between knowledge and power, and that the particular cultural-historical structure of this relationship is a persistently useful field of inquiry. But although the allure of postmodern (and adjacent) theories may have faded, actual projects whose conductors offer alternatives to modernist logics have proliferated. I argue here that this insight is actually incorporated into so many political projects, across silos, that it has been difficult to trace. It is articulated and demonstrated by the multitude of civic projects coming from every possible margin (indigenous, queer, feminist, neocolonial, scientific, religious fundamentalist, spiritual, ecological). My project stands on this critical epistemological foundation. Following scholars like Shiv Visvanathan (2006), Linda Tuhiwai Smith (2012), Arturo Escobar (2008, 2020), and Boaventura de Sousa Santos and his colleagues (2007, 2018), the concept of epistemic activism is a notion of civic world-making as a contested, historically contingent project that is multiple to its core.

\section{Knowledge Practices Within Social Theory}

In this paper, I examine civil society (and the cross-field subcategory of epistemic activist projects) as a set of practices, not as a structural object or concept. The civil society of Tahrir Square and Occupy are easy to characterize as things located in space and time: There is civil society! But to say so only further mystifies what researchers are trying to understand. Many of the field's researchers examine the role of civil society in relation to the state, examining what civil society "means" or "wants" in particular places and times. This, too, is mystifying: Civil society is not an agenda that, once discovered, can be measured and evaluated. Any robust understanding of such a broad concept must enable the parsing of differences, the unfolding of time, the interactions among actors/actants. In a more grounded approach, researchers can examine any particular mass civic event as a particular consequence of civil society practices. The questions become not essentialist but empirical: What practices make this particular sort of civic project?

Practice theory comes out of a 20th-century argument, mostly within the discipline of anthropology, about the relationship between human action and the codification or analytic sense-making thereof. This project is perhaps most clearly delineated in Bourdieu's The Logic of Practice (1990). Practice theory became a powerful theoretical and, ultimately, methodological response to structuralist approaches to mapping systems of power and human organization. This approach 
was later elaborated by a wide variety of anthropologists who asserted that a particular sort of human action, resistance to domination, can: 1) best be understood through their everyday practices (e.g. Willis, 1978; Scott, 2008), and 2) teach the field a great deal about the systems and dynamics of power and domination to which they respond (Ferguson, 1990). In this way, the complex worlds of everyday practices become a key to understanding power, not the other way around.

A robust concept of civil society arguably requires a meaningful way of engaging human intent, action, and the ways that structures are shaped by practices (not simply vice versa). For Sherry Ortner, one of the most attractive aspects of practice theory is its robust engagement with the relationship between structure and agency. Ortner insists that a viable practice theory, which is attentive to power, history, and culture, is the most powerful theoretical lens-and methodological guide-to studying contemporary human conditions across contexts. The virtue of practice theory is that it takes as its starting point the notion that the world is contingent, with structures in constant negotiation through human actions, "the idea that the world is 'made' - in a very extended and complex sense, of course - through the actions of ordinary people also meant that it could be unmade and remade" (Ortner, 2006, pp. 16-17).

Beyond its conceptual foundation, the methods of practice theorists are those with which they best interrogate everyday as well as intentionally collective practices of resistance. Elizabeth Povinelli (2011) takes the relationship between worlds and makers, infused by critical theories of power and culture, quite a bit further than her predecessors by examining the particular violence at work on the margins and in the creases of late liberalism. In Economies of Abandonment, Povinelli attempts "to address the question of the endurance, let alone the survival, of alternative forms of life in the gale force of curtailing social winds" (p. 10). There are many such ways to make practice theory accountable to the forces of power and history, to account for not only the dominant and easily-legible modes of civic action but those outside the moral—and, I would argue, epistemic — norms of dominant state and market structures.

For me, the roots as well as the reach of practice theory enable a methodological focus on the organization of people's intentional encounters to make things happen in the civic sphere. I study epistemic activist projects through and around meetings, because it is there that I find it possible to access the real-time "knowledge practices" that produce epistemic projects. 


\section{Meetings as Site and Lens}

In a concrete sense, the practices of civil society can be described largely in terms of who meets, in what setting, and how. The collective relationality of the meeting, which I define as an intentional encounter of people for a purpose, ${ }^{1}$ is the primary container for the production of collective knowledge and power outside the state and markets.

In some sense, this is so obvious as not to be worth stating. But in another sense, scholars often ask questions that circle around the importance of relationality without attending to its actual practices. They make much of the networked character of social movements and civic organizations alike, to mapping and measuring who knows and influences whom. Major public events or civic campaigns are described in painstaking detail, often through the work of journalists who interview some combination of assigned spokespeople and whoever happens to be on the scene of a main event (protest, press conference, riot, court appearance, etc.). But the micropolitics of interaction in meetings - the events that form the architecture for every civic event-usually remain uninterrogated. Often, neither reporters nor scholars even bother to let on whether planning meetings or post-event meetings occurred, let alone the who, when, where, and how of such meetings. And almost never do scholars of social movements or civic projects reveal the meaning-making processes of smaller factions within the projects: the side-meetings, the conspiratorial decision-making, the grumbling, the meetings to strategize otherwise. Indeed, the collective processes of sense-making and identity-making often seem of far less concern than the sense-making of the researcher or reporter who is there to tell the story.

To be sure, ethnographers of civil society organizations and movements often describe project meetings and micro-politics. But by the time they engage in sectorwide analysis (spanning, e.g., the relationship between donors and NGOs and movements), researchers usually lose this focus on everyday practices, or reduce it to the mapping of nodes of connection and largely speculative interpretation into what these connections signify or produce. Such network analysis is necessary and useful to map knowledge diffusion, and to answer questions about the scale and structure of a particular civil society project. Yet network analysis does not enable scholars to see the relationship between different project iterations across both structure-based and field-based silos of civil society.

Below are brief sketches of two extremely distinct civil society projects. These are projects that would not ordinarily be combined in a single social scientific or theoretical project. Their actors do not encounter one another in competition for

\footnotetext{
${ }^{1}$ The definition of meeting is controversial: Many meeting scholars and practitioners believe three people are necessary to constitute a meeting, and some believe that meetings require particular rules related to decision-making and dialogue. For a discussion amongst diverse anthropologists and sociologists about this topic, please see the introduction to "Meeting Ethnography" (Sandler \& Thedvall, 2017).
} 
resources or in collaborative endeavors; they do not network with one another or attend the same meetings. They inhabit distinct silos. In many ways, the boundaries of these silos make sense: They correspond to many concrete differences. Yet despite the differences that have justified the development of academic, funding, and popular consciousness silos, these silos elide vital similarities that I aim to address with this project.

I argue that the most salient similarities among these three projects are their knowledge practices, the specific ways that their actors make truths and make truths matter. It is impossible to see knowledge practices by looking at a project's function, attempting to measure its effectiveness, mapping its internal structure, or deconstructing and interpreting its aims or discourses. Knowledge practices are in essence politics, ways of mobilizing epistemic agendas, and as Richard Freeman, Steven Griggs, and Annette Boaz note (2011), politics must be examined in terms of practices. The only methods that serve are thus ethnographic_one must "read" epistemic activist projects from the inside.

Meeting ethnography is a method for doing so. Once one has looked through meetings as a way of tracing the epistemic dimension of civic action, I suggest one might see, across the broad field of civil society, a great diversity of projects whose actors are engaged in a struggle not over what power thinks, but how.

\section{Case 1: Demonstrating Epistemic Unity in a U.S. Reform Coalition}

\section{CLI: A Civic Reform Coalition}

Civic coalitions are a form of civil society particular to municipalities in the United States. Their specific politics vary, depending on the ideologies and positions of the individuals involved, but they typically consist of local business, civic, professional, and volunteer interests coming together to improve life for people in a particular geographic area. Coalitions are sometimes issue-based, particularly if they were developed out of a particular philanthropic or government funding stream (e.g., in response to drug abuse or violence). But many are standing civic coalitions whose members address a wide range of issues that people in the local area face. The epistemics of civic coalitions are distinctly localist: that solutions to local problems must emerge from local experiences and knowledge. Civic coalitions produce "local knowledge" through particular data-gathering practices. These may occur through official settings like town halls or issue forums, where community members voluntarily provide input. But most coalition leaders are committed to broader "participation" and recognize that this requires more active or direct methods.

The Coalition for Local Initiatives (CLI, a pseudonym) is one such organization. CLI was started in the early 1990s by business executives from the large and diverse city of Crossroads (a pseudonym) who attended a "public-private 
partnerships"-inspired seminar with state government officials. They became upset that millions in tax dollars were allocated for their community without any significant participation or consultation of local people. Over the course of several years, they developed a coalition consisting of renegade bureaucrats, high-profile business executives, and civic and community leaders. To ensure broad participation of community members, the coalition staff engaged community organizers to train neighborhood site coordinators to engage low-income neighborhood people. As the board president (an international corporate executive) put it, site coordinators were trained to become "case managers for the neighborhoods: an extraordinary model!"

CLI had become a large and powerful organization by the time I encountered it in my 2006-2007 fieldwork. But a large and diverse local coalition organization is inherently unstable. In order for coalitions to act as collective bodies, their members must constitute themselves continually through projects, through the doing. They become and remain real only through their collective constitution. This is where meetings come in. Meetings, I argue, are the key technologies for bringing the coalition into this being-through-doing.

A wide variety of meetings are designed to provide the "architecture" (Sandler \& Thedvall, 2017) of CLI (Sandler, 2017), including:

- 1-1 meetings to build relationships and leadership

- internal meetings to build and influence collective agendas

- internal meetings to develop and influence coalition strategy

- meetings with outsiders to spread localist and "bottom-up" methodology

- meetings to hold public officials accountable

- a perpetual stream of meeting-planning meetings and meeting-debrief meetings

- demonstration meetings

In the next section, I will describe in detail a relatively rare but quite important type of coalition meeting: a demonstration of a successful project, in this case the funding of a school-based health clinic. With this meeting, I illustrate the epistemic project of the Coalition for Local Initiatives.

The most interesting aspect of CLI is the diversity of actors brought together through its projects. Notably, CLI's diversity includes social identities, access to power, structural interests, and also ideologies. CLI's actors espouse a very wide range of politics and ideologies, including ardent beliefs in both weak and strong government, more and less corporate power, public and private solutions, empowerment and sanction of the marginalized. Through interviews conducted with the actors who attended the demonstration meeting, described below, I discovered a particularly wide range of motivations and ideologies for supporting the schoolbased health clinic, including: Addressing the specter of urban violence (the board member quoted "the rough beast" of Yeats' poem); empowering the Black community; building the kingdom of God on Earth; redistributing government resources in a more effective way; building a community self-help culture so that people would not rely on the government; increasing civic engagement; aiding gentrification and economic development; redressing corporate greed, addressing health disparities, 
and promoting women's leadership. In CLI, as we shall see, everyone is left to their own ideology; what is shared is an epistemic commitment to local knowledge. Periodically, this shared commitment must be demonstrated.

\section{The Meeting}

It was $6 \mathrm{pm}$ in a low-slung one-story wing of a large Protestant church in an urban neighborhood of a major metropolitan area. Twelve years earlier, an eight-lane highway had cut this neighborhood off from the rest of the city. In 2006, when this meeting occurred, it was difficult to get in or out of this neighborhood. Most public and private services had located on the other side of the highway, where gentrification was uneven but possible and customers were more assured. On the night of the meeting, people began to arrive at the church to discuss the development of a public school-based health clinic that would bring medical, dental, and mental health screening services to the neighborhood for the first time since the highway, and that would make them affordable for neighborhood residents and free for school children and their families. This meeting was the culmination of hundreds of smaller meetings over the course of two years of organizing. The sense of anticipation and build-up was palpable in the intentionality of the meeting design.

Three coalition staff members-business casual in pressed khaki and buttondown shirts - stood near the door. There were rectangular folding tables set up at the back of the room with food: boxes of pizza, a bowl of fruit salad, a plate of carrots, bags of Chips Ahoy cookies, cups and juice, Styrofoam plates and napkins. Neighborhood families with children who filed in were given programs by a coalition staffer who they knew. They were directed to nudge their children to the back to pile food on plates, after which the children were hushed and shuffled away to a separate childcare room. A white man and woman in what I could only discern as old-money-nice clothing-both uber-wealthy Coalition board members-came in and were immediately greeted by coalition professional staff, then handed programs and gently guided the other way from the food tables, to seats at the front of the room facing the podium. The coalition's deputy director, a middle-aged Black woman, placed her coat next to them, effectively assuring they would not have unknown seat-neighbors. Meanwhile, two executives of a private hospital, both wearing drab business suits, had walked in, found the one coalition staffer one of them knew, shaken hands stiffly, and sat down as near the door as possible. A woman in a gray skirt and cotton sweater, with a bulging briefcase, rushed in as the program was about to start and smiled apologetically at one of the coalition staffers, collapsed in a heap in the nearest folding chair, and took out her laptop. She was the state program officer overseeing the large government grant for the health clinic, and the only person who seemed to know no one.

The school-based site coordinator, a white male community organizer with the coalition who had been working with the parent leaders on this project for three years, beckoned two parent leaders (both Black women) once they emerged from dropping 
off their children. He quietly huddled with them as they expressed anxieties, went over prepared talks, and calmed one another's nerves with words of encouragement. Other parents made their way from the food in the back to the back rows of chairs and took seats, smoothing their dresses or pants and fiddling with the one-page programs. The neighborhood church pastor and the school principal, both of them Black men, came in separately and each seemed to make a show of greeting as many people as possible individually. They each walked through aisles to formally shake hands with all the people in suits, said hello to a parent or two in each aisle, backslapped the male coalition professionals and hugged the female deputy director. They were constantly in motion, each separately leaning in to talk conspiratorially with coalition staff, walking to the back to grab food, walking around and crouching down to speak with different neighborhood folks who were seated, and getting back up again to get more food. When they and the khaki'd coalition door staff were the only people standing, all but one staffer took seats and the pastor strode to the podium, welcomed guests to this special event, and offered a short Christian prayer for the food.

Before I describe anything about what went on during the meeting, it should be clear that the substantive assertion of any sort of collective identity was impossible in this context. Any attempt to assert collective interest, to tell a collective story, to create a sense of forced solidarity, would have exposed fractures that were not under the surface but were apparent to all through the aesthetic presentation and bodily comportment of the diverse actors. From the outset, it was clear to all that each of these actors was there for his or her own self-interest, and there was an uneasy sense that the project might not be able to hold the diversity of these interests. The "work" each contingency had done had varied so greatly. The local parents had been organizing one another and pressuring their city council representative to help get zoning changed. The elite board members have made their direct phone calls to encourage the passage of an unprecedented package of state grants. The hospital executives had been half-blackmailed with lawsuits and half-bribed with sweetened contracts to join the deal. CLI staff had been managing each of these pieces, and many more. And most of these people had never encountered one another directly. They had different stakes, leveraged different forms of power, held different visions. In this room, for a moment there, it seemed that there might be no center to hold.

The program itself was short. There were many brief, carefully-crafted acknowledgements that without each contingency's work, this clinic would not be built. The core of the meeting, for everyone, was the three neighborhood women leaders' speeches. They were extraordinarily well prepared, both in their language and delivery. The first presented a sort of testimonial-style account of what it is like to live in a part of the city that has been geographically and structurally cut off from all health services. She attested to her own children's school absences for lack of dental services, her four-bus-ride experiences traveling to the hospital emergency room with her toddler for complex ear infections, how her own mother died of cervical cancer because no one in their neighborhood knew where to get affordable gynecological exams. The next speaker talked about the group of parents that came together to study different models of health clinics. She did not talk about the study, only the group; how much they learned, how capable they felt. The third talked about what 
her life was going to be like once the clinic went in; that she might be able to keep a job for longer than from the end of one child's flu to the beginning of the next; that she wouldn't have to choose between going to work and taking her kids to the dentist; that her asthmatic ten-year old wouldn't ever again nearly die because she couldn't keep an appointment across town with a doctor who would give them a renewed inhaler prescription.

These were carefully crafted statements. There was no discussion of personal obligation, of deservedness, of the role of the government, of rights or responsibilities. There was no blame or demand-and no thanks, either. Just moving stories of what had been the reality without the clinic, and what would now be possible with it. After the women spoke, one of the coalition's most elite board members got up, shook each of their hands, and said a few words about how the Coalition was about bringing people together around amazing stories like these. He thanked them for sharing and said he was glad to hear their words and be a part of this project with everyone in this room. This elite board member-a billionaire, in fact-did not take credit, appropriate, condescend, or provide any framework for the women's statements, beyond the importance of all coming together around local needs. The lack of specificity was quite deliberate; what was not said created space for everyone to feel more at home in their folding chairs, to imagine the project as their own.

After the meeting concluded, the health clinic project development was done. Each of these so-different bodies could move back out into their own worlds and worldviews; building the clinic would commence immediately, and the coalition would go on to work on its many other projects.

\section{What the Meeting Made}

CLI demonstration meetings such as this one are where the local knowledge that has been produced (through a tapestry of other meetings) is assembled in public. It is a demonstration that the project resulting from this local knowledge assemblage - the health clinic-does not become an ideological cudgel. No one owns the meaning, and the project can thus remain sutured to each actor's diverse ideologies and interests. The demonstration meeting enables CLI's core epistemic project to serve as the glue that holds the coalition together.

Furthermore, when one looks at this meeting as an ethnographer, it is clear that CLI's core practices are not any of the things proponents of the mainstream civil society approach would have them be. Their core practices are not "rational deliberation," nor anything resembling the communicative action central to a Habermasian public sphere. They are not decision-making occasions, either nominally or substantively. Nor are CLI's meetings anthropological ritual performances of the legitimacy of hierarchies or solidarity. Instead, CLI's core meeting practices are epistemic events. Large meetings such as these, at the end of a project, are vital occasions for CLI to constitute - to "make" - the coalition as a whole, by demonstrating the 
epistemologically unified, performatively singularized "local" subject to the multiple wildly diverse actors who comprise it.

Hegemony, as Gramsci noted a century ago, is never total; it requires constant sense-making work through "intellectual and moral leadership" of both individuals and institutions (Gramsci, 1971, p. 57). I would characterize CLI as a counterhegemonic project of a particular sort. Its particularly vigilant knowledge practices are necessary for the coalition to survive the constant pull of the hegemonic notion that the world is divided based on ideological interest, material interest, or neoliberal measures of efficiency and outcome. Through diverse meeting forms, CLI shifts how people produce knowledge about the conditions of urban social suffering. Coalition participants know, all together, that the health clinic is necessary based on the experiences of those who will use its services. Each is free to believe the clinic advances their own interest-laden ideologies of the state, the private sector, philanthropy, and cultural politics. This contingent, ever-becoming coalition is thus constituted in and through practices of believing differently and knowing together.

\section{Case 2: Place-Based Movements and the Epistemic Politics of Listening}

I now turn to a more ideologically cohesive, social movement form of epistemic activism. Many social movements aim, as Raúl Zibechi (2010) says, to "disperse" power directly to people struggling for lives of dignity, rather than to consolidate power in intermediary institutions or representative bodies. These movements' form of participatory democracy involves an insistence on mass-impact and yet humanscale social and political relations. Although ubiquitous and largely legible to the general populous in many parts of the world, in the U.S. place-based social movements have taken hold in a particularly hybrid-American form. These are movements that coalesce not around an abstract idea or funding silo (health, education, housing, immigration, etc.), but around the particular experiences of a specific group of people in a struggle to stay, return to, or protect their homes, communities, and/or land and natural resources. There are many such movements and organizations in the United States. However, they are generally outside the public eye. To date, there have been virtually no serious mainstream media reports of Black-led farms and land trusts, ${ }^{2}$ prison abolition movements, indigenous sovereignty projects, or local municipal movements to occupy or collectivize control over space.

In U.S. cities, these local movements coalesce around the notion of anti-displacement, the right to stay in one's home and neighborhood despite

\footnotetext{
${ }^{2}$ Two notable examples of Black-led land projects include the Black- and Indigenous-led farming project Soul Fire Farm (Penniman, 2018) and Jackson Rising, a comprehensive, anti-neoliberal, alternative economic project in Jackson, Mississippi, to build the collective ownership and power of the city's majority Black poor residents (Akuno, Nangwaya, \& Cooperation Jackson, 2017).
} 
capitalist and imperialist threats. Anti-displacement movements ${ }^{3}$ are generally either ignored or wildly mischaracterized within the dominant media of the United States. There is extremely little coverage of collective resistance to eviction, foreclosure, lack or erosion of local ordinances protecting renters, and the predatory banking and real estate development industry that controls these mechanisms of displacement. Even when they cover large public protests, the U.S. media do not do the work of communicating to the public that the people involved-not their leaders or advocates but their members - conceptualize themselves as part of a broad and interconnected social movement, intimately connected to other anti-displacement movements around the world. When seen at all, mainstream institutions generally dismiss such movements as uncompromising, radical, and distinctly illiberal, or as naively romantic.

In this section, I describe one such group: Movement for Justice in El Barrio, an anti-displacement movement comprised mostly of low-income immigrant women in East Harlem, New York. For place-based movements like Movement for Justice in El Barrio, the vision is one of both autonomy and solidarity, "a world in which many worlds fit," as the Zapatistas say, a logic of multiple forms of collective thriving whose adopters eschew capitalist, imperial, and colonial "global designs" (Mignolo, 2000). This vision can be seen in practice through the particular dynamics of diverse movement meetings. Through meetings, movements mobilize their epistemic agenda: that what is true, and what to do about it, can only be understood through deep listening. Listening is the core epistemological practice that Movement for Justice in El Barrio mobilizes through its particular meeting landscape and leads to all other-more visible-movement practices.

\section{Meetings to Mobilize Listening}

Movement for Justice in El Barrio engages in at least four types of meetings. ${ }^{4}$

First, they have a range of internal meetings. I have not been to any of these meetings, because I am not a member and am not conducting research inside the organization. I know only that they happen, because they discuss the ways these meetings structure their work in their pedagogical meetings (see below). Internal meetings take place with people who are "in the struggle," that is, who are directly

\footnotetext{
${ }^{3}$ See the Right To The City movement, which consists of many organizations made up of people fighting foreclosure, gentrification, development policies, predatory landlords, and so forth. See Brenner, Marcuse, and Mayer (2012), and https://righttothecity.org/.

${ }^{4} \mathrm{My}$ relationship with Movement for Justice in El Barrio has been to facilitate their members' and organizers' access to universities to teach about their work and introducing students and colleagues to their work through both invitations and visits. My reflections in this section stem from what I have learned as a colleague and friend of the organization. Movement for Justice members and organizers have read and approved each draft of this section and have contributed information to ensure the accuracy of this description of their work. For more information on this movement, please see https://www.movementforjusticeinelbarrio.org/.
} 
affected by gentrification and the threat of displacement. In Movement for Justice's situation, the problem of displacement involves bad landlords, bad government, bad zoning policy, and other threats to the rights of people in El Barrio to live with dignity in their community. Movement organizes building by building (in East Harlem, apartment buildings are large). First, a person with a problem related to their housing approaches Movement for Justice to meet, and the organizers ask if they are willing to organize people in their building. If so, the organizing looks like going door to door through the building to have brief 1-1 meetings, where they listen to tenants' problems and inquire as to whether they want to work with their neighbors toward solutions. The majority of a building's residents must then attend a meeting in the lobby of the building and vote (twice) to become members of Movement. Movement's buildings then hold regular meetings to listen to their neighbors and make decisions about how to struggle together, what fights to take on, and so forth. In addition to building-level strategy meetings, Movement for Justice holds large monthly member meetings to share experiences and make organization-level decisions.

Like many movement organizations, Movement for Justice operates on the principle of self-representation-"each person has voice and vote," as they say-and there is a focus on speaking and listening in order to arrive at collective, consensusbased solutions. David Graeber chronicles some of the issues that arise when radical consensus-based meetings are held by mostly white, relatively nomadic global justice direct action groups (Graeber, 2009). But such meetings look rather different among people like the women of El Barrio, who face a shared set of threats to their homes and shared community.

When home, community, or land is at stake, meetings tend to look less like a protracted debate over ideas, identities, strategies, and logistics, and more like a layered set of testimonies to personal experiences and concerns. Arguments are interwoven with testimony, over time, to form a sort of tapestry comprised of many intimately positioned political opinions. In this way, sense-making more so than linear decision-making characterizes these collective meeting spaces. The methodology of sense-making requires a meeting form crafted to give absolute priority to unmediated testimonial and collective listening. I have experienced such generalassembly style meetings as a guest and occasional participant in various North American movement settings and have also seen video footage of many movements that seem to be striving toward this general-assembly form.

Movements based on shared struggle for place also have to consider how to invite in outsiders to that place, what the outsiders' roles should be, and how to seek and accept support. What do such solidarity meetings look like for place-based movements? Movement for Justice in El Barrio invites people in similar struggles across different contexts to share stories of their struggles through mass meetings called Encuentros, inspired directly by the methods of the Zapatistas in Chiapas. The only goal of Encuentro-style meetings is the development and demonstration of solidarity, a form of relationality based on listening in order to develop and demonstrate empathy with one another's struggle. Unlike other epistemic movement demonstration meetings, those holding Encuentros make no space for collective 
sense-making or persuasion. Mutual recognition is the task, and this happens through sharing stories of struggle. In addition to Encuentros, Movement for Justice members also takes their testimony directly to others by sharing documentary films and answering questions with what they call "people of good heart" in various cities, organizations, and universities. Their goal in these visits is both recognition in the struggle, and also to raise funds in support of their work.

Third, Movement for Justice in El Barrio holds pedagogical meetings for outsiders. These take the form of free workshops in their neighborhood each summer, and locally sponsored workshops when they travel. Movement's workshops are explicit teaching-style meetings, using popular education methods to provoke reflection on various elements of their actors' organizing approach. The most interesting of these to students, from my observation in several rounds of offered workshops, is "the politics of listening," a participatory workshop that involves sharing the Zapatista's 2006 listening campaign and applying its lessons to participants' own work. Placing listening front and center introduces a radically different epistemology. Students must speak only from their own perspectives, not from above or outside. The structure all but requires a humble curiosity about displacement, rather than argument or critique, in order to open up space to continue listening. In my experience of Movement's workshops at my university, a wholly distinct interactive atmosphere is created when the skills of listening are prioritized.

Finally, for Movement for Justice in El Barrio the struggle itself often involves meeting-based encounters with structures of power. In these encounters, Movement for Justice members (not outside allies) occupy public spaces and meetings, making visible their demands for recognition and structural capitulation or accommodation. In each action, members demand not simply a particular policy change, but a different logic than that of those in power. This logic is that of constantly and systematically listening to the people most affected, or what the Zapatistas call "governing by obeying" (mandar obrediciendo). The Zapatistas, as Mariana Mora shows in her ethnographic work with them, organize manndar obrediciendo in a very systematic way; it is a challenging logic of governance (Mora, 2017). When Movement for Justice in El Barrio members confront power directly, they expose the broad gap between local rule and mandar obrediciendo; they do not request to be heard, but demand that government obey their communities.

Movement for Justice's protest politics to expose this gap and counteract the displacement forces that affect them often include disrupting "normal" liberal democratic meetings, where the logic of collaboration between capital and elected representatives is on display. For example, Movement for Justice members decided to strategically disrupt a local Community Board meeting. "Community Boards" in New York City are appointed by elected officials and tasked with discussing and giving input on proposed city policies. Community Boards have no legislative power; their positions are symbolic. Furthermore, participation on a Community Board is often seen as a stepping-stone to elected office. Because members are appointed, do not necessarily live in the neighborhood, and serve at the will of elected officials, there is a strong incentive for CBs to approve - and thus provide a neighborhood-level stamp of legitimacy for-whatever city policies are proposed. 
Thus, it was unusual when in 2017 Community Boards began taking positions against the liberal Mayor's re-zoning plan. The media began paying attention to these incidences of "community" pushback. In El Barrio, Community Board 11 was not expected to take a strong stand against the Mayor's re-zoning plan, which would likely result in the displacement of many of the low-income immigrant families who lived there. Movement for Justice members wanted it known that the interests of people who lived in the community were not being represented, so they decided to strategically attend this meeting. Captured on video, a large group of women with their children showed up to the meeting, held in a small room. They did not participate in the mode of liberal governance on display, but instead began stating their experiences as an interruption, making it clear that their collective demands were being ignored. When the board was forced to make clear that "compromise" with capital and placation of local residents was in fact the agenda, Movement members chanted (in Spanish) "we demand a firm "no"” over and over, eventually marching out.

Movement members have also highlighted the gentrification designs of both greedy landlords and a progressive mayor in the streets and to the press. They have traveled to Europe, with the support of international allies, to proclaim the cruelty and greed of a British developer who sought to purchase vast amounts of property in their Harlem neighborhood and displace them. Their listening campaign in the UK ultimately prevented the sale. And they have driven out several other predatory landlords by similar means of public declaration that is in effect a shaming: Those who govern must listen to the people or be shamed for their failure to do so. The community's experiences must not be ignored in the development of their neighborhood. As Movement's members put it in their vision statement (which they often share in videos and at events): "[T]he houses belong to the people who live in and care for them...no one should own more houses than they can live in."

\section{Listening Leads and Mobilizes New Agendas}

Listening, not a static mission statement, has led Movement to choose which struggles that affect members of their community to take on. Members have conducted many consultas del barrio or neighborhood consultations in several formats to learn what issues the community faces and for the community to decide what should be at the center. Through community surveys, they organized testimonial-style town hall meetings with members of the community, which led the movement to new agendas. Movement has also decided not to take on campaigns, such as a city policy that threatened the income of local street vendors, based on listening to those who were directly affected.

Movement for Justice has also taken on new activities in recent years based on its internal listening practices in combination with emerging political events. For example, in 2018 and 2019, Movement members turned their attention to the Cayuga Centers, a local nonprofit organization that they discovered through an investigative journalist's report had been contracted by Homeland Security and 
Immigration and Customs Enforcement (ICE) to receive and hold migrant children who had been separated from their families. Detention, deportation, and the specter of family separation threatens many Movement for Justice in El Barrio's families; when the members discovered that children were being sent to be detained in their own neighborhood, they felt compelled to center solidarity with the children and their parents and held several actions to ask that their solidarity be heard.

In March of 2020, COVID-19 began to hit Movement's members very hard. Most Movement members support their families with low-paid, contingent work. Many work as home aids, in restaurants and food trucks, and as house cleaners and custodians. When the pandemic hit, some were deemed "essential" and were also among the least protected workers. Many have lost jobs, with no access to unemployment assistance or federal stimulus aid due to their undocumented immigration status. Many others have fallen quite ill, with little access to medical care aside from hospital emergency rooms. Tragically, several members died from the virus during the first half of 2020. Movement members immediately pivoted their work to address this crisis, for the first time coordinating basic services such as food, health information, support for sick and grieving families, and other necessary aid. In addition, during COVID-19, Movement for Justice in El Barrio has continued to call for the freedom of all immigrants detained in New York.

Movement for Justice has quickly made this major-if temporary—shift in its orientation from anti-displacement policy and protest campaigns to work focused largely on direct aid to families; indeed, I know of no other non-profit organizations that enacted such a dramatic pivot during the early months of the COVID-19 crisis. Movement's actors did so because it was impossible to sideline their members' urgent needs when listening was at the center of their approach to the work. Their work during this time has remained true to a politics of listening. They have listened internally to members' stories and needs in order to learn what their work should consist of during the pandemic. They have held both private and public pedagogical meetings to provide allies with opportunities to listen to members' lived experiences, support them, and help them engage more people. For allies such as myself and my students, listening to Movement members' lived experience and analysis has exposed the current iteration of the gap produced by a government that fails to "govern by obeying" the people. Movement for Justice in El Barrio aims its epistemic politics of listening at keeping in sharp relief the gap-and exploitative dependence-between middle-class U.S. citizens, whose experiences of the pandemic have been mediated by government aid, food and service delivery, and ample opportunities to work and learn from home, and families with mixed immigration status, "essential" low-income work status, and no access to capital, whose experiences of the pandemic have been far more brutal. 


\section{Conclusion}

I have outlined two quite different sorts of epistemic activist projects operating within a broadly conceived field of civil society in the United States. By attending to how each produces its truths and makes them matter, I hope to suggest the utility of using the epistemic activism concept as a lens through which to see civil society in a different way. I have suggested that "meeting ethnography," in particular, is a methodology for looking through that lens, for making inquiries across a diverse field of civic projects.

With this relational approach to epistemic activism, I focus on the way projects' proponents communicate what their projects are, not as static narratives but as relational practices in time and space (whether physical or virtual). The ethnographic mapping of narrative practices through meeting ethnography catapults scholars out of obfuscating silos without allowing researchers to fall into an abyss of abstraction. I hope that this project increases the field's capacity to look across civil society's ever-shifting silos (albeit awkwardly, much as actors move across them), ultimately to begin to make inquiries across the field of civil society as a whole. By using relational events - meetings - as a methodology for mapping epistemic activism, I suggest that one may be able both to examine extraordinarily diverse projects in the vernacular of their particular practices and also to consider them within the same theoretical frame. Taking epistemic activism as the object of study has enabled me to engage civic projects that range from the two described in this paper-a large municipal coalition and a grassroots place-based movement organization-to the scientistic movement for evidence-based social policy, emerging movements for epistemological pluralism, and movements against state violence. I expect that this approach should also enable scholars to engage alternative economic movements as well as what are now called "alt-right" movements.

Elizabeth Povinelli (2011, p. 10), whose examination of alternative social projects in "Economies of Abandonment" is a selective guide to civic projects that grow in the neglected folds of late/predatory/disaster capitalism, asks:

If the possibilities of new forms of life dwell and are sheltered within the variation between the force of existing and the power of acting within these intensified zones of being and not being, then what does immanent critique demand of those who live in these zones?

I argue, ultimately, that it is the role of civil society scholars to describe and contend with the various "forms of life," or social projects, that emerge from the variegated pressures and structures of our time. Contending with the epistemic critiques that animate such projects requires drilling down to their relational practices. Civil society scholars are thrust into the intensified zones of the projects we engage through "meeting ethnography," ethnography of and through meetings, through which the ethnographer focuses on mapping civic projects that enact diverse models and modes of being (and not being, and becoming, and answering the question "for whom?"). It is in these intensified zones that one witnesses the proliferation of zealous resistance against hegemonic ways of knowing, as well as the emergence of 
alternative narratives whose proponents may engage and even produce new forms of life, if given the chance.

\section{References}

Akuno, K., Nangwaya, A., \& Cooperation Jackson. (Eds.). (2017). Jackson rising: The struggle for economic democracy and Black self-determination in Jackson, Mississippi. Ottawa: Daraja.

Bherer, L., Dufour, P. \&, Montambeault, F. (2016). The participatory democracy turn: An introduction. Journal of Civil Society, 12, 225-230. https://doi.org/10.1080/17448689.2016.1216383

Bourdieu, P. (1990). The logic of practice (R. Nice, Trans.). Stanford, CA: Stanford University Press. (Original work published 1980)

Brenner, N., Marcuse, P., \& Mayer, M. (Eds.). (2012). Cities for people, not for profit: Critical urban theory and the right to the city. London: Routledge. https://doi.org/10.4324/9780203802182

Casas-Cortés, M. I., Osterweil, M., \& Powell, D. E. (2008). Blurring boundaries: Recognizing knowledge-practices in the study of social movements. Anthropological Quarterly, 81, 17-58. https://doi.org/10.1353/anq.2008.0006

Cooke, B., \& Kothari, U. (Eds.). (2001). Participation: The new tyranny? London: Zed.

de la Cadena, M., \& Blaser, M. (Eds.). (2018). A world of many worlds. Durham, NC: Duke University Press.

de Sousa Santos, B. (2007). Beyond abyssal thinking: From global lines to ecologies of knowledges. Binghamton University Review, 30(1), 45-89.

de Sousa Santos, B. (2018). The end of the cognitive empire: The coming of age of epistemologies of the South. Durham, NC: Duke University Press.

Escobar, A. (2008). Territories of difference: Place, movements, life, redes. Durham, NC: Duke University Press.

Escobar, A. (2020). Pluriversal politics: The real and the possible (D. Frye, Trans.). Durham, NC: Duke University Press.

Fanon, F. (1963). The wretched of the earth (C. Farrington, Trans.). New York: Grove Weidenfeld.

Ferguson, J. (1990). The anti-politics machine: 'Development', depoliticization and bureaucratic power in Lesotho. Cambridge, UK: Cambridge University Press.

Freeman, R., Griggs, S., \& Boaz, A. (2011). The practice of policy making. Evidence \& Policy, 7, 127-136. https://doi.org/10.1332/174426411X579180

Graeber, D. (2009). Direct action: An ethnography. Oakland: AK.

Gramsci, A. (1971). Selections from the prison notebooks of Antonio Gramsci (Q. Hoare \& G. Nowell, Ed. and Trans.). London: Lawrence and Wishart.

Howell, J., \& Pearce, J. (2001). Civil society and development: A critical exploration. Boulder: Lynne Rienner.

Mignolo, W. D. (2000). Local histories/global designs: Coloniality, subaltern knowledges, and border thinking. Princeton, NJ: Princeton University Press.

Mora, M. (2017). Kuxlejal politics: Indigenous autonomy, race, and decolonizing research in Zapatista communities. Austin, TX: University of Texas Press.

Ortner, S. B. (2006). Anthropology and social theory: Culture, power, and the acting subject. Durham, NC: Duke University Press.

Osterweil, M. (2013). Rethinking public anthropology through epistemic politics and theoretical practice. Cultural Anthropology, 28, 598-620. https://doi.org/10.1111/cuan.12029

Penniman, L. (2018). Farming while Black: Soul fire farm's practical guide to liberation on the land. White River Junction: Chelsea Green.

Povinelli, E. A. (2011). Economies of abandonment: Social belonging and endurance in late liberalism. Durham, NC: Duke University Press. 
Sandler, J. (2017). Meetings all the way through. In J. Sandler \& R. Thedvall (Eds.), Meeting ethnography: Meetings as key technologies of contemporary governance, development, and resistance (pp. 106-125). New York: Routledge.

Sandler, J., \& Thedvall, R. (Eds.). (2017). Meeting ethnography: Meetings as key technologies of contemporary governance, development, and resistance. New York: Routledge. https://doi. org/10.4324/9781315559407

Scott, J. C. (2008). Weapons of the weak: Everyday forms of peasant resistance. New Haven, CT: Yale University Press.

Smith, L. T. (2012). Decolonizing methodologies: Research and indigenous peoples. London: Zed. Spivak, G. C. (2003). Three women's texts and a critique of imperialism. In R. Lewis \& S. Mills (Eds.), Feminist postcolonial theory: A reader (pp. 306-323). New York: Routledge.

Visvanathan, S. (2006). Alternative science. Theory, Culture \& Society, 23, 164-169. https://doi. org/10.1177/026327640602300226

Williams, G. (2004). Evaluating participatory development: Tyranny, power and (re)politicisation. Third World Quarterly, 25, 557-578. https://doi.org/10.1080/0143659042000191438

Willis, P. (1978). Learning to labour: How working class kids get working jobs. London: Routledge. https://doi.org/10.4324/9781351218788

Zibechi, R. (2010). Dispersing power: Social movements as anti-state force (R. Ryan, Trans.). Oakland: AK.

Open Access This chapter is licensed under the terms of the Creative Commons Attribution 4.0 International License (http://creativecommons.org/licenses/by/4.0/), which permits use, sharing, adaptation, distribution and reproduction in any medium or format, as long as you give appropriate credit to the original author(s) and the source, provide a link to the Creative Commons license and indicate if changes were made.

The images or other third party material in this chapter are included in the chapter's Creative Commons license, unless indicated otherwise in a credit line to the material. If material is not included in the chapter's Creative Commons license and your intended use is not permitted by statutory regulation or exceeds the permitted use, you will need to obtain permission directly from the copyright holder. 